\title{
A1-Mn 合金の再結晶時における析出*
}

\section{長浜 勝介** 高橋 正弘**.三木 功**}

\author{
Precipitation during recrystallization of Al-Mn alloys*
}

UDG $669.715^{\prime} 74: 621.785 .7$

NAGAHAMA Katsusuke**, TAKAHASHI Masahiro** and MIKI Isao**

This study was undertaken to investigate the precipitation phenomena during recrystallization of supersaturated and deformed $\mathrm{Al}-\mathrm{Mn}$ alloys.

Specimens used were $\mathrm{Al}-1.34 \mathrm{wt} \% \mathrm{Mn}$ and $\mathrm{Al}-1.29 \mathrm{wt} \% \mathrm{Mn}-0.05 \mathrm{wt} \% \mathrm{Si}$ alloys. They were cold-rolled after solution treatment at $640^{\circ} \mathrm{C}$, and were heated at several temperatures of $300 \sim 600^{\circ} \mathrm{C}$. Experiments were carried out by measurements of hardness and electrical resistivity and electron microscopy.

The results obtained were summarized as follows:

(1) Precipitation of manganese was accelerated by cold working. This effect was particularly marked when the specimen was annealed at temperatures not higher than $400^{\circ} \mathrm{C}$.

(2) At lower temperatures $\left(\leqq 400^{\circ} \mathrm{C}\right)$, precipitation process reached near the equilibrium state before the end of recrystallization process. Therefore, the nucleation and growth occurred in dislocations or dislocation cell structures (subboundaries). Therefore, the acceleration of precipitation would be due to the easier nucleation in these lattice defects and easier growth by pipe diffusion.

(3) At higher temperatures ( $\geqq 450^{\circ} \mathrm{C}$ ), precipitation occurred after the end of recrystallization. In this case, the nucleation took place also in the lattice defects, but the growth occurred in the recrystallized matrix. Therefore, the acceleration of nucleation was only due to the easier nucleation.

(4) The addi ion of $0.0 \mathrm{jwt} \% \mathrm{Si}$ accelerated the precipitation process of deformed $\mathrm{Al}-\mathrm{Mn}$ alloys and made precipitates finely distributed. This acceleration was supposed to be related with the retardation of recrystallization due to the finely distribitted precipitates.

(5) Almost all the precipitates were identified as $\mathrm{Al}_{6} \mathrm{Mn}$ in the both alloys. However, $\mathrm{Al}_{6} \mathrm{Mn}$ precipitates were in globular form at lower temperatures and rectangular thin plates at higher temperatures. It was the first identification ever experienced in the world that the rectangular thin plates of $\mathrm{Al}_{6} \mathrm{Mn}$ precipitates were observed in the from of rectangular thin plates.

(6) The crystallographic relation between the rectangular plates and aluminum matrix was found to be $<110>_{\mathrm{Al}} / /<001>_{\mathrm{Al}_{6} \mathrm{Mn}}$ and $\{111\}_{\mathrm{Al}} / /\{110\}_{\mathrm{Al}_{6} \mathrm{Mn}}$ and their habit planes were supposed to be $\{111\}_{\mathrm{Al}}$.

The rectangular plates seemed to be coherent with aluminum matrix at the earlier stage of precipitation.

(Received March 18, 1971)

1. 緒言

マンガンはアルミニウム合金の添加元素として良く用 いられており，拡散，再結晶および析出現象に関連し て，その挙動を把握することは重要である。

$\mathrm{Al}-\mathrm{Mn}$ 系の実用材料である 3003 合金の場合, 従来よ
りその熱処理条件と再結晶現象などの関係については， 非常に多くの研究 ${ }^{1 \sim 8)}$ が行なわれている。

しかし一般の市販 Al-Mn 合金では不純物として 0.1 \%以上の鉄が含まれるため，鋳造時に鉄化合物が晶出 し，その鉄化合物の晶出と同時にあるいはその後の熱処 理時に，マンガン原子が晶出物中に吸収されたりあるい

* 第39回軽金属学会秋期大会 $(45-11)$ にて発表した。

** 株式会社 日本軽金属総合研究所（静岡県蒲原町）

Nippon Light Metal Research Laboratory, Ltd. (Kambara, Shizuoka-Ken) 
Table 1 Chemical composition of specimens ( $w \mathrm{t} \%$ )

\begin{tabular}{c|c|c|c|c|c|c|c|c}
\hline & $\mathrm{Mn}$ & $\mathrm{Si}$ & $\mathrm{Fe}$ & $\mathrm{Gu}$ & $\mathrm{Ti}$ & $\mathrm{Mg}$ & $\mathrm{Cr}$ \\
\hline $\mathrm{A}$ & 1.34 & $0.00^{1)}$ & 0.005 & $<0.001$ & $<0.001$ & $<0.001$ & $<0.001$ \\
$\mathrm{~B}$ & 1.29 & 0.05 & 0.006 & $<0.001$ & $<0.001$ & $<0.001$ & $<0.001$ \\
\hline
\end{tabular}

は排出されるような現象が考えられ，マンガン原子の挙 動は複雑である。したがつてマンガン原子の挙動のみを 知ろうとする場合には鉄晶出物の影響を極力避ける必要 がある。

$\mathrm{Al}-\mathrm{Mn}$ 合金の析出現象に関する研究は, マンガンが 鋳造時に過飽和に固溶されやすいため, 最大固溶量以上 に固溶させた強制固溶体からの分解過程について，かな り行なわれている ${ }^{9 \sim 18)}$ 。また最大固溶量以下で鉄含有量 の少ない合金については,太田 ${ }^{19)}$, 清水 ${ }^{20)}$, Ferrari $^{21)}$ および Oelschlägel ${ }^{22)}$ らの研究がありつぎのようなこと が解明されている。

$\mathrm{Al}-\mathrm{Mn}$ 過飽和固溶体からの析出は非常に遅く, $\mathrm{Al}-$ $1.0 \% \mathrm{Mn}$ 合金の場合, 平衡状態に達するのに $450{ }^{\circ} \mathrm{C}$ で 1,000 時間を要する ${ }^{21)}$ 。析出による硬化は非常に小さ い19,20)。また析出相は斜方晶の $\mathrm{Al}_{6} \mathrm{Mn}$ 相と体心立方晶 の $\mathrm{G}$ 相その他に $\mathrm{G}^{\prime}$ 相が存在する ${ }^{22)}$ 。 $\mathrm{Al}_{6} \mathrm{Mn}$ 相は不規則 な形の丸味を帯びた板状 ${ }^{22)}$ で，アルミニウムマトリック スと (315) $\mathrm{Al} / /(001) \mathrm{A}_{6} 1 \mathrm{Mn} ，[130] \mathrm{Al} / /[100] \mathrm{Al}_{8} \mathrm{Mn}$ という関 係 ${ }^{19)}$ を保持している。また $\mathrm{G}^{\prime}$ 相は平たい針状でマトリ

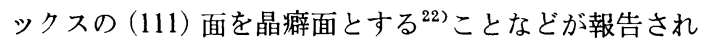
ている。

一方筆者らは以前に $\mathrm{Al}-\mathrm{Fe}$ 合金について研究 ${ }^{23)}$ を行 ない，析出速度の遅い系でも泠間加工を行なつてから加 熱すると, 加工組織の消失する再結晶時に加工組織の助 けによつて析出が促進されること, そして鉄化合物の析 出によつて再結晶が遅れること, ケイ素の微量添加が興 味ある影響をおよぼすことなどを報告した。

マンガンも鉄と同じ遷移金属に属するので, $\mathrm{Al}-\mathrm{Mn}$ 合金においても同様の効果が生ずるものと期待される。

これに関しては, Polesya ${ }^{24)}$ らがX線回折によつて再 結晶過程が析出過程に拉よぼす影響について研究を行な つているが，その機構などについては解明されていな W。

本研究は不純物として鉄の含有量の少ない Al-Mn 合 金を用いて，その過飽和固溶体を泠間加工し，それを加 熱した時に起こる析出過程を電気抵抗の測定によつて, またそれと同時に起こる再結晶過程をかたさの測定によ つて調べると同時に, 析出物の形状, 構造, 分布などを 電子顕微鏡観察によつて検討した。またケイ素添加の効 果についても， $\mathrm{Al}-\mathrm{Fe}$ 系に見られたような変化があるか 否かを検討した。

\section{2. 実験方法}

99.99\%以上の高純度アルミニウムと $99.9 \%$ \%ンンガ ンおよびケイ素を用いてアルミナルツボ中で溶解し，金 型に鋳込んで $70 \times 200 \times 1,000 \mathrm{~mm}^{3}$ の鋳塊をえた。こ の鋳塊の表面 $5 \mathrm{~mm}$ を面削したのち，640 ${ }^{\circ} \mathrm{C}$ で 2 時間加 熱して溶体化処理を行ない水冷した。これらの試料の内 の一部を熱間圧延なしで $93 \%$ の冷間圧延を行なつた。え られた試料の化学組成を Table 1 に示す。

冷間圧延を行なつた試料を冷間圧延しなかつた試料と ともに, 塩浴中で $300^{\circ} \mathrm{C}$ から $50^{\circ} \mathrm{C}$ の間隔で $600^{\circ} \mathrm{C}$ ま゙の各 温度に所定の時間加熱保持した。その時に起こる再結晶 現象と析出現象をかたさ, 電気抵抗の測定および電子顕 微鏡による薄膜の直接観察によつて調べた。なお試料が 所定の温度に到達するのに 2 分から 3 分を要した。これ は約 $10000^{\circ} \mathrm{C} / \mathrm{hr}$ の昇温速度に対応する。

かたさの測定は常温でビッカース硬度部により荷重 5 $\mathrm{kg}$ で行ない, 電気抵抗の測定は恒温 $\left(23^{\circ} \mathrm{C}\right)$ に保つた部 屋で常に試料を一定の温度に保つて, 渦電流法（シグマ テスター）によつて行なつた。

電子顕微鏡観察には，98\%の冷間圧延を行なつて厚さ $0.3 \mathrm{~mm}$ の板から切り出した直径 $3 \mathrm{~mm}$ の小円板を熱処 理し, これをジェット研磨法によつて中心部を薄くした のち, 仕上げ研磨を行なつて中心部に小孔をあけそつ周 囲を観察した。

\section{3. 実験結果}

\section{1 冷間加工を行なわない場合の電気抵抗変化}

$\mathrm{Al}-1.3 \% \mathrm{Mn}$ および $\mathrm{Al}-1.3 \% \mathrm{Mn}-0.05 \% \mathrm{Si}$ 合金につい て, 溶体化後泠間圧延をせずに直ちに加熱保持した時の 電気抵抗変化を Fig. 1 および Fig. 2 に示す。

Fig. 1 は $\mathrm{Al}-1.3 \% \mathrm{Mn}$, Fig. 2 は $\mathrm{Al}-1.3 \% \mathrm{Mn}-0.05 \%$ Si 合金に対するものである。Fig. 1 (a) および Fig. 2 (a) は電気抵抗の等温加熱曲線である。低温の $300^{\circ} \mathrm{C}, 400^{\circ} \mathrm{C}$ では 1,000 分経過しても析出はほとんどなく電気抵抗の 減少は見られない。 $550{ }^{\circ} \mathrm{C}$ 付近で析出速度が速くなり， 電気抵抗が大きく減少する。Fig. 1 と Fig. 2 を比較す るとわかるように, ケイ素が添加されると析出速度が少 し速められる。この様子は Fig. 1 (b) および Fig. 2 (b) に示した等時加熱曲線によつてより明白となる。この図 は(a)で示した等温曲線に执いてある一定時閒での電気抵 
抗変化を温度に対してプロットしたものである。 $550{ }^{\circ} \mathrm{C}$ 付近に谷が生じこの温度領城で析出速度の早いことがわ

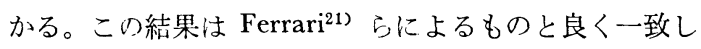
た。

この図において $550^{\circ} \mathrm{C} ， 20$ 時間では平衡状態の約 $60 \%$ の析出が，また 600 Cでは20時間でほぼ $100 \%$ の析出が起 こつている。ケイ素を添加した場合もこの析出量にほぼ 同じ結果をえた。これらの値は加丁を行なつて析出速度
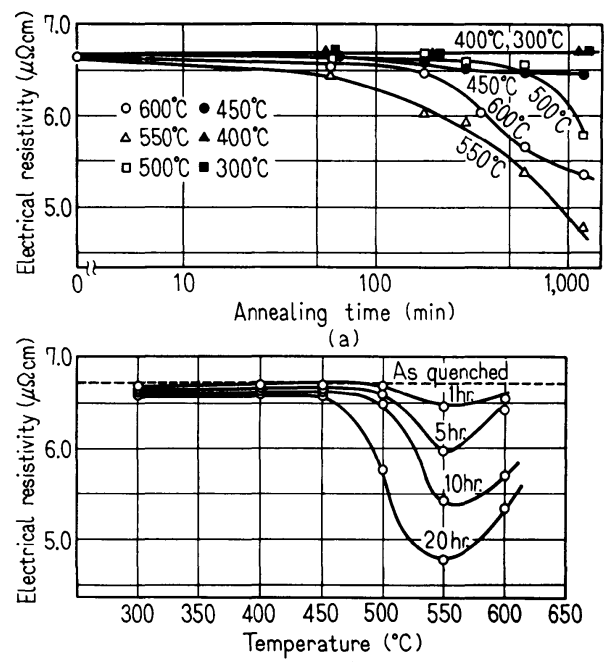

(b)

Fig. 1 Electrical resistivity change of non-deformed $\mathrm{Al}-1.3 \mathrm{wt} \% \mathrm{Mn}$.

(a) Isothermal curve (b) Isochronal curve
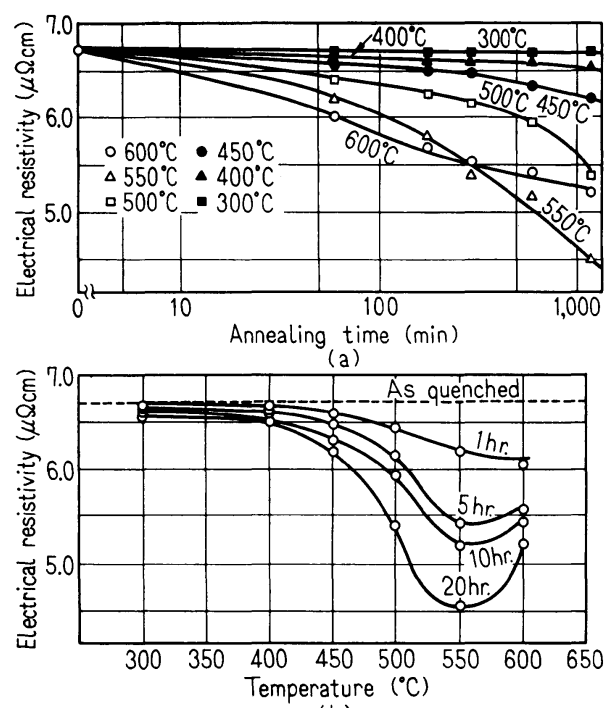

(b)

Fig. 2 Electrical resistivity change of non-deformed $\mathrm{Al}-1.3 \mathrm{wt} \% \mathrm{Mn}-0.05 \mathrm{wt} . \% \mathrm{Si}$.

(a) Isothermal curve

(b) Isochronal curve
を速めた試料を用いて約15日間加熱を行ないほぼ平衡状 態に近い時の電気抵抗を求め, 焼入れ直後に打ける電気 抵抗との差を $100 \%$ として概算したものである。

\section{2 加工を行なつた場合の電気抵抗変化}

Fig. 3 および Fig. 4 はそれぞれ $\mathrm{Al}-1.3 \% \mathrm{Mn}$ および $\mathrm{Al}-1.3 \% \mathrm{Mn}-0.05 \% \mathrm{Si}$ 合金を溶体化後 $93 \%$ の泠間圧延を 行なつて, 各温度に加熱保持した時の電気抵抗変化であ る。

この場合は冷間加工時に生じた格子欠宿の消失による 電気抵抗の減少と, マンガンの析出による減少とが同時 汇起こる。格子陷の消失による寄与分はマンガンの析 出による寄与分に比べ無視できるほど小さいが，Fig. 3 および Fig. 4 には加工組織の消失による寄与分を差し 引き，析出による抵抗減少分のみが示されている。

加工を行なうと析出速度が速まり, $550^{\circ} \mathrm{C}$ および $600^{\circ} \mathrm{C}$ での曲線において 1,000 分付近で曲線が平らになり，ほ ぼ平衡状態に近づいていることがわかる。またさらに特 徵的な事は, 加工しない場合にはほとんど変化のなかつ た $350^{\circ} \mathrm{C}$ るいは $400^{\circ} \mathrm{C}$ での変化量が非常に大きくなるこ とである。この低温での析出速准はケイ素が添加される と一層影著となる。

上述の現象は Fig. 5 (a) および Fig. 6 (a) に示した電 気抵抗の等時曲線によつてより明白に理解できる。加工 を行なうと $\mathrm{Al}-1.3 \% \mathrm{Mn}$ でも $\mathrm{Al}-1.3 \% \mathrm{Mn}-0.05 \% \mathrm{Si}$ 合 金でも低温の $350^{\circ} \sim 400^{\circ} \mathrm{C}$ 付近と高温の $500^{\circ} \sim 550^{\circ} \mathrm{C}$ 付近 の 2 力所に変化量の大きい谷が生ずる。 $400^{\circ} \mathrm{C}$ 以下の低 温に抢ける谷は加工しなかつた場合には認められなかつ たものである。

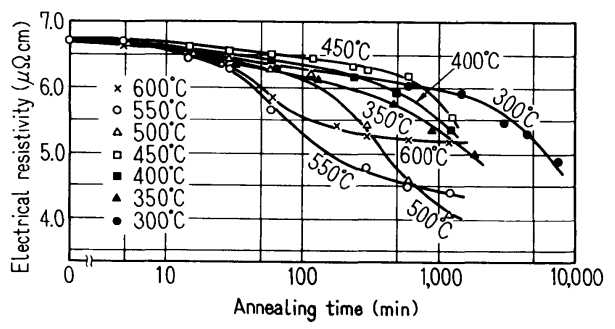

Fig. 3 Isothermal heating curve of electrical resistivity in cold-rolled $\mathrm{Al}-1.3 \mathrm{wt} \% \mathrm{Mn}$.

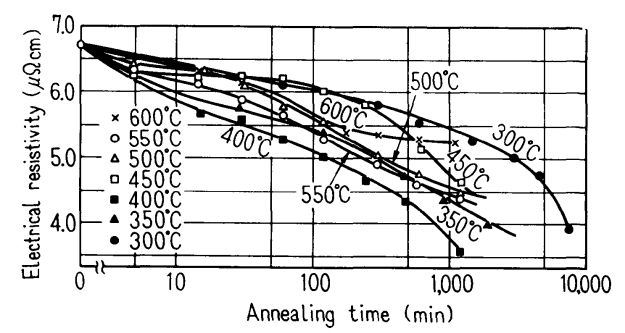

Fig. 4 Isothermal heating curve of electrical resistivity in cold-rolled $\mathrm{Al}-1.3 \mathrm{wt} \% \mathrm{Mn}-0.05 \mathrm{wt} \% \mathrm{Si}$. 
$350{ }^{\circ} \mathrm{G}$ で20時間加熱した場合の析出量は，加工しない 時には $0 \%$ であつたが，加工を行なうと $\mathrm{Al}-1.3 \% \mathrm{Mn}$ 合 金では50\%，ケイ素が添加されると $80 \%$ に達する。そし て400Cではほほぼ100\%である。

高温の $550{ }^{\circ} \mathrm{C}$ で20時間加熱した場合, ケイ素がある場 合もない場合もほぼ $100 \%$ の析出が起こつており, 加工. しない場合よりも析出量は大である。一方 $600^{\circ} \mathrm{C} て ゙ も 100$ \%近い析出が起こつているが，この温度では加でしない 場合とほとんど差がない。

以上のごとく, 高温加熱におけるケイ素の析出促進の 効果は低温加熱の場合に比して小さい。

\section{3 かたさの変化}

Fig. 5 (b) 掞よびFig. 6 (b) に溶体化後, 93\%の冷閒 圧延を行なつた後, 各温度に加熱した時のかたさの等時 加熱曲線を示す。 $\mathrm{Al}-\mathrm{Mn}$ 合金ではマンガンの析出によ る硬化は小さいと報告 ${ }^{19,20)}$ されており，またFig. 5, Fig. 6からわかるように再結晶の終了が早くしかも析出速度 も早い高温で加熱し, 再結晶が終了して析出が起こつて いると考えられる段階に達しても，かたさの上昇は見ら れなかつたこと拉よび後で電子顕微鏡観察の項で示め寸
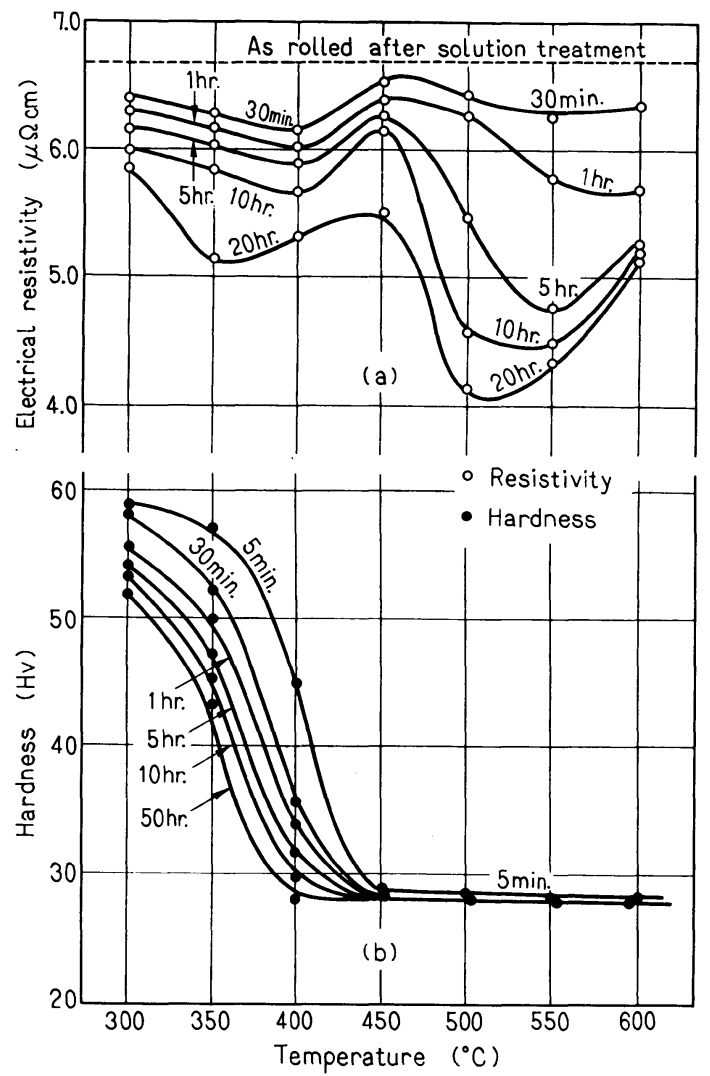

Fig. 5 Isochronal heating curve of electrical resistivity (a) and hardness (b) in cold-rolled Al-1.3 wt. $\% \mathrm{Mn}$.
ように, 本研究の場合析出物の分布が粗であることか ら, 析出による硬化は再結晶にともなう軟化に比べ無視 できるほど小さいものと考えられる。

低温の $300^{\circ} \mathrm{G}, 350^{\circ} \mathrm{C}$ では再結晶による軟化は遅く, 10000 分経過しても完全に軟化しないが，高温の $450^{\circ} \mathrm{C，}$ $500^{\circ} \mathrm{C}, 550^{\circ} \mathrm{G}$ および $600^{\circ} \mathrm{G}$ では軟化が速く 5 分以内に軟 化し再結晶が完了する。 $400{ }^{\circ} \mathrm{C}$ における変化を比較する とよくわかるように，ケイ素が添加されると軟化が遅れ る。

Fig. 5, Fig. 6 の (a) および(b)よりつぎのことが推測 できる。 $400{ }^{\circ} \mathrm{C}$ 以下の低温では再結晶の進行が遅く, 再 結晶の終了と析出の終了（平衡状態に到達すること）が 時間的に一致するか $\left(400^{\circ} \mathrm{G}\right)$ あるいは析出が終了しても 再結晶がまだ完了していないか $\left(300^{\circ} \mathrm{C} ， 350^{\circ} \mathrm{C}\right)$ のいずれ かに相当する。すなわち低温側での析出は加工組織がか なり残存している状態で進んでいることがわかる。した がつて低温での析出促進は加工組織の存在が関係してい ると考えられる。

$450{ }^{\circ} \mathrm{C}$ よりも高温の場合は, 再結晶が終了してから析

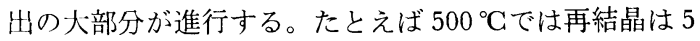

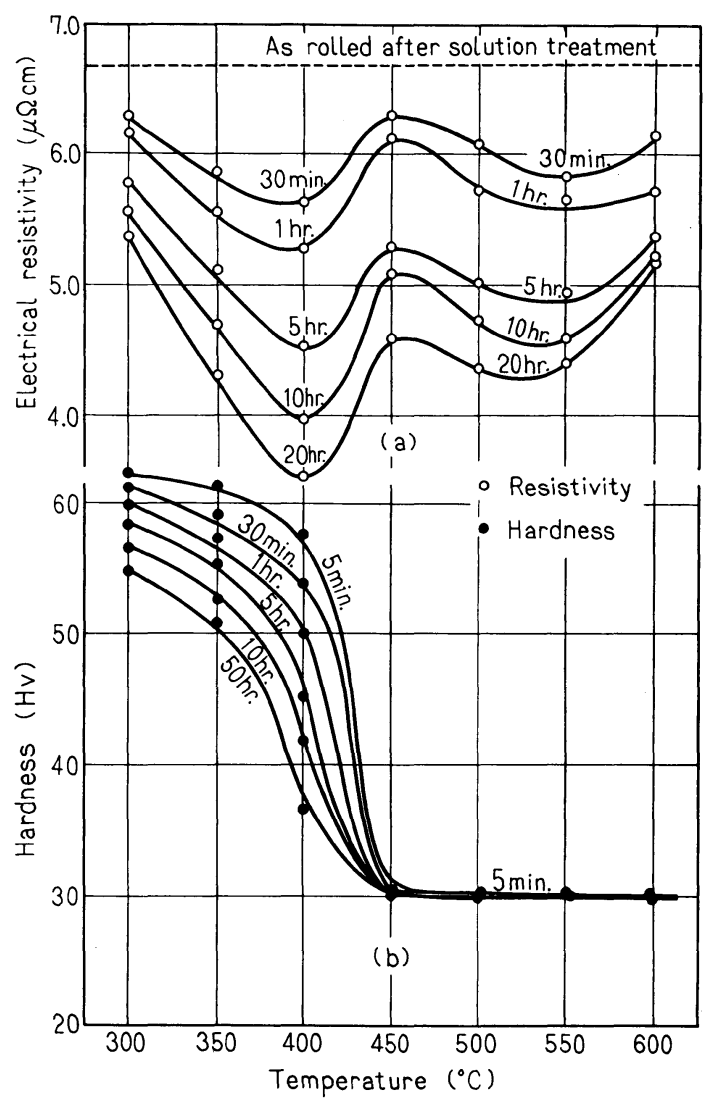

Fig. 6 Isochronal heating curve of electrical resistivity (a) and hardness (b) in cold-rolled Al-1.3 wt. $\% \mathrm{Mn}-0.05$ wt. $\% \mathrm{Si}$. 
分以内に完了するが，その間に析出はその $3 \%$ \%進行す るに過ぎない。また加工した時の析出速度は再結晶後に 進行する場合でも加工しない場合に比べかなり速く，析 出の初期つ核生成の段階ではやはり加工組織の助けを借

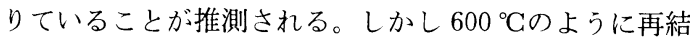
晶の進行がきわめて速い場合には，析出核が加工組織に 生成する時間がないため，加工した場合も加工しない場 合もその析出速度に差がない。

\section{4 昇温速度の影響}

Fig. 7 (a) および (b) は Al-1.3\% Mn 合金のそれぞれ 電気抵抗およびかたさの変化におよぼす昇温速度の影響 を示したものである。 $640{ }^{\circ} \mathrm{C}$ で溶体化処理した後 $90 \% の$ 冷間压延を行なつてから， $100^{\circ} \mathrm{C} / \mathrm{hr}, 1,000^{\circ} \mathrm{C} / \mathrm{hr}$ および $10,000{ }^{\circ} \mathrm{C} / \mathrm{hr}$ の速度で各温度に昇温させ所定温度に到達 後直ちに急冷した試料のかたさと電気抵抗の変化であ る。

電気抵抗変化より昇温速度の速い試料では析出量が少 ないが，昇温速度が遅、と析出量が増加することがわか る。しかし $10,000^{\circ} \mathrm{C} / \mathrm{hr}$ といつた速い速度でもその温度 に到達した時点で，すでにある程度の析出が起こつてい る。

昇温速度が遅いと高温に滞在する時間が長いので $(500$ ${ }^{\circ} \mathrm{C}$ 沉到達するのに $100^{\circ} \mathrm{C} / \mathrm{hr}$ では 5 時間, $10,000^{\circ} \mathrm{C} / \mathrm{hr}$ では 3 分である。析出量が多くなるのは当然であるが， かたさの変化からわかるよらに，それにもかかわらず再 結晶軟化が遅机るということは注目寸べきことである。 すなわち再結晶軟化する前に析出する析出物の量が多い ほど再結晶軟化が遅れており, これらの析出物が再結晶 を阻止しているのではないかと考えられる。
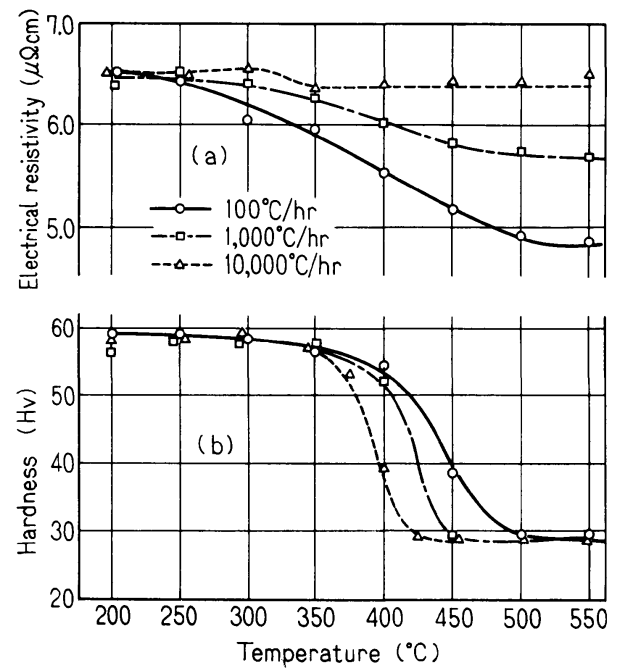

Fig. 7 Effect of heating rate on the change of electrical resistivity (a) and hardness (b) in cold-rolled $\mathrm{Al}-1.3 \mathrm{wt} \% \mathrm{Mn}$.
Fig. 8 は Al-1.3\% Mn- $0.05 \% \mathrm{Si}$ 合金を溶体化掞よび冷 間圧延したのち, $1,000^{\circ} \mathrm{C} / \mathrm{hr}$ の速度で加熱して各温度に 保持した時のかたさと電気抵抗の等時曲線である。

Fig. 6 に示したように, $10,000^{\circ} \mathrm{C} / \mathrm{hr}$ の昇温速度を用 いた時には， $450{ }^{\circ} \mathrm{C}$ で比較するとよく理解できるが，こ の温度での軟化は速くしかも析出量も少ない。しかし $1,000^{\circ} \mathrm{C} / \mathrm{hr}$ という遅い昇温速度の時には再結晶の軟化が 非常に遅らされると同時に，析出も非常に進行する。

昇温速度の遅い時には, 所定の温度に到達するまでの 間に析出が起こり, そのため再結晶が遅らされ, 加工組

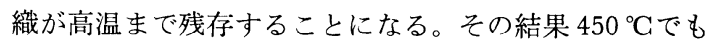
析出の進行が速いものと考えられる。

\section{5 電子顕微鏡観察}

Photo. 1 は Al-1.3\% Mn 合金を溶体化後, 冷間圧延 を行なつて $(\mathrm{A})$ は $100^{\circ} \mathrm{C} / \mathrm{hr}(\mathrm{B})$ は $1,000^{\circ} \mathrm{C} / \mathrm{hr}$ 抢よび(C)は $10,000^{\circ} \mathrm{C} / \mathrm{hr}$ の速度で昇温して $450^{\circ} \mathrm{C}$ に到達後, 直ちに 急冷した時の組織である。昇温速度が遅いほど析出量が 多く, また(A)では加工組織が見られ再結晶が完全に終わ つていないことがわかり，Fig. 7 の結果と良く一致す る。昇温速度の速い(C)でも析出物は見られる。しかしそ の量はわずかで析出物の見られない領域が多い。
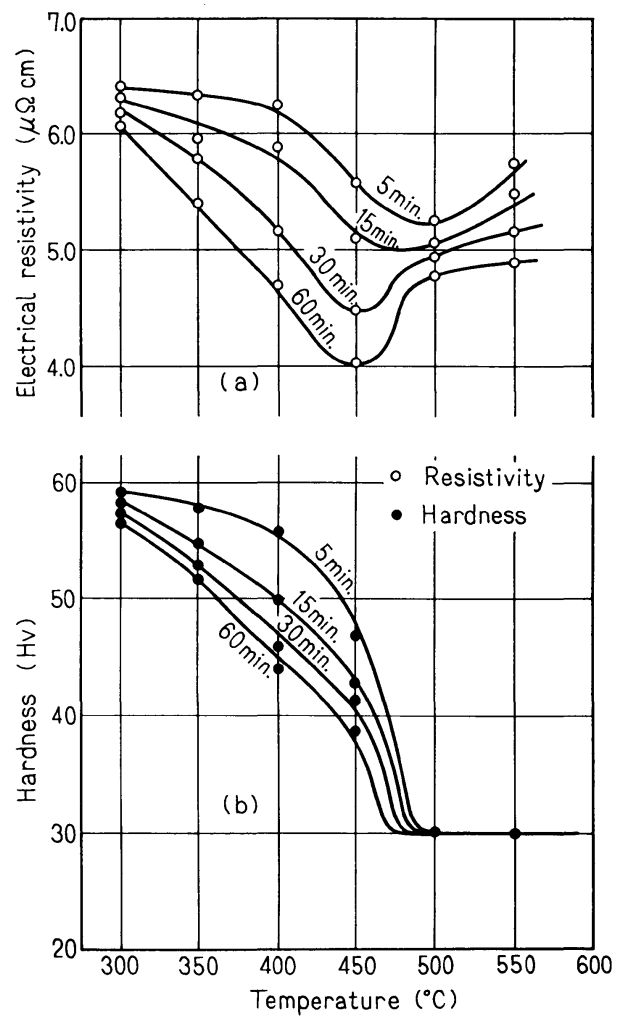

Fig. 8 Isochronal heating curve of electrical resistivity (a) and hardness (b) in cold-rolled $\mathrm{Al}-1.3$ wt $\% \mathrm{Mn}-0.05 \mathrm{wt} . \% \mathrm{Si}$, heated in $1,000^{\circ} \mathrm{G} / \mathrm{hr}$. 
これらの析怙物はその分布がいずれも粗であり，昇温 の間に転位や虾粒界あるいは粒界などに生じたものと考 えられる。

つぎにFig. 7 で示したように $10.000^{\circ} \mathrm{C} / \mathrm{hr}$ で界温す ると電気抵抗の等時曲線に 2 つの谷が生じ, $450{ }^{\circ} \mathrm{C}$ 以上: と $400 \mathrm{C}$ 以下で析归の様子が異なることが才かつたの で、これらの 2 つの温度領域で加熱した時の組織観繁を 行なつた。

Photo. 2 は400C以ドの低温で加熱したものである。 (A) よ $\mathrm{Al}-1.3^{\circ}{ }_{0} \mathrm{Mn}$ 合金を $350^{\circ} \mathrm{C}$ で 125 時閏，(B)は $\mathrm{Al}-1.3$ ${ }_{0}^{0} \mathrm{Mn}-0.05^{\circ}{ }_{0} \mathrm{Si}$ 合金を $400^{\circ} \mathrm{C}$ で 1 時間加熱した時のもの である。曲粒界や転位がかなり残存しており，再結昆が 終了していないことがわかる。また析㨫物は粒界, 亚粒 界扩よび転位線上に丸味を带びた塊状で析计している。 粒界，亚粒界の析计物は大きく，転位線上の析出物は小 さい。析帅は加1:組織で起こつて抢り，電気抵抗㧍よび かたさからえた結果と良く一致している。これらの析计

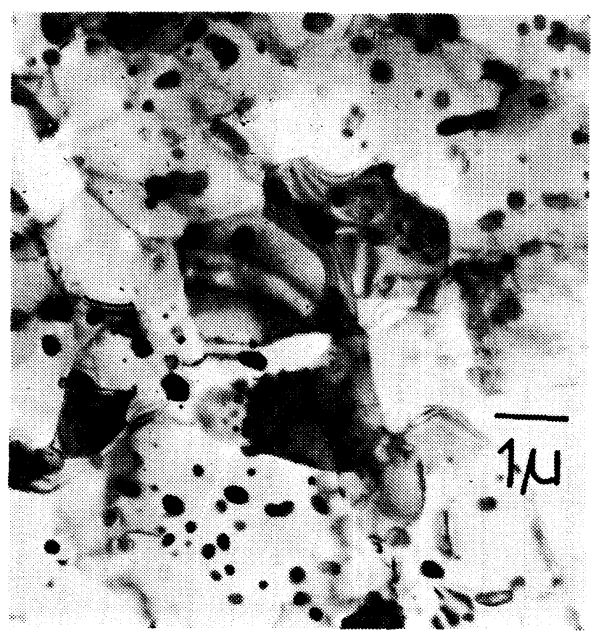

(A)

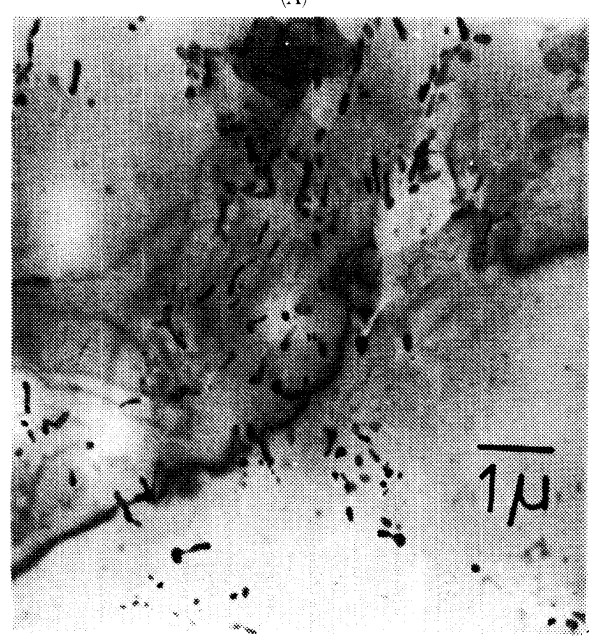

(c)
物は電子線回折により, $\mathrm{Al}_{6} \mathrm{Mn}$ 相であることが確認され た。(C)は $\mathrm{Al}-1.3^{\circ}{ }_{0} \mathrm{Mn}-0.05^{\circ} \mathrm{Si}$ を $400^{\circ} \mathrm{C}$ で50時間加熱し たものである。再結晶がほぼ終了した段階である。析壮 物は全て丸味を带びた塊状で大小 2 種類に分けられる。

Photo. 3 は $\mathrm{Al}-1.3 \% \mathrm{Mn}$ 命食を $550^{\circ} \mathrm{C}$ で加熱した時の 組織である。(A)诗試料が $550{ }^{\circ} \mathrm{C}$ 達すると同時に急冷し たものであり，(B)は10分，(C)，(D) は30尔また(E)は 1, 200 分の加熱保持したものである。

(A)から才かるように， $10,000^{\circ} \mathrm{C} / \mathrm{hr}$ といら速い少温速

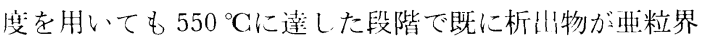
などに生じている付域が見门れる。しかしその量は非常 に少なく，试料の大部分の領域には析性らしきものは 認められない。この段階で，既に再結晶はほぼ終了して

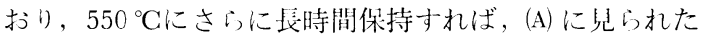
析壮物の成溒扩よび再結晶したマトリックスでの新たな 析㺫が起こるものと考えら的る。

(B)は持結昆したマトリックスから生じた析壮物で，析

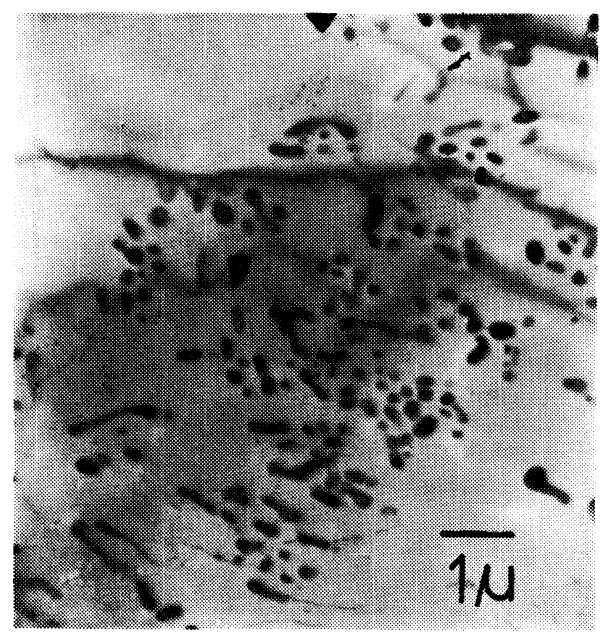

(B)

Photo. 1 Effect of heating rate on electron microscopic observation of cold-rolledAl-1.34/0 $\mathrm{Mn}$, heated to $450^{\circ} \mathrm{C}$ at heating rate of $100^{\circ} \mathrm{C} / \mathrm{hr}$ (A), $1,000^{\circ} \mathrm{C} / \mathrm{hr}(\mathrm{B})$ and $10,000^{\circ} \mathrm{C} / \mathrm{hr}$ (C) respectively. 
出のごく初期段階のものであり，非常に小さい。析出物 の周辺にコントラストが見られるが、こ机は歪み場によ るものと考えられる。しかし一般のコヒーレントな析出 物の場命と異なり，その分有は不均一である。したがつ てこれらの析计物は再結晶終了前に存在した転位線など に核生成したものと考えられる。そして，その核は昇温 の間に生じており，(A)にはその内異常に成流したものが 観察されたものと考えられる。

(C)は(B)で示した析川物が成主したものである。析归物 は長方形の板で，板の内部に紐い絽模様のコントラスト が見える。これは後述するように析訬物とマトリックス の間に生じた界面転位と考えられる。

(D)は(C) と同様30分加熱したもので, 析归物の分布は不 均一で，以前あつたと考えら扎る転位線あるいは亚粒界 に析出したものが，頭をそろえて成犊している様子がわ かる。

(E)は 1,200 分加熱した時のものであるが，析蜘は大

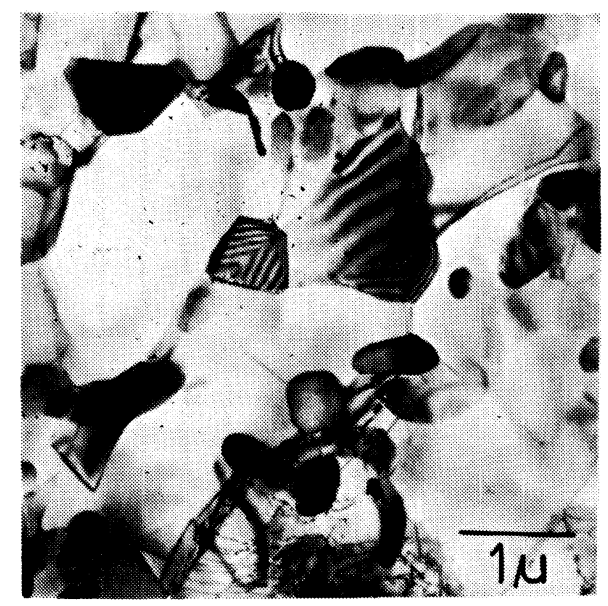

(a)

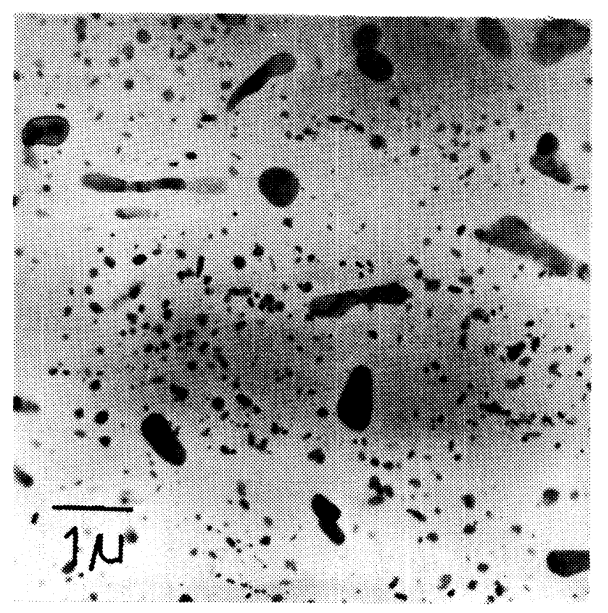

(c)
きく成長している。Photo. 2 および Photo. 3 で見られ る析出物の大部分は $\mathrm{Al}_{6} \mathrm{Mn}$ 相であること, また $\mathrm{G}^{\prime}$ 相 もわずかながら存在することが電子線回折によつて確認 された。 $\mathrm{Al}_{6} \mathrm{Mn}$ 相は主方形の板状のほかに不規則な形 の板状のものも認められる。

Photo. 4 はケイ素を添加した Al-1.3\% Mn-0.05\% Si 合金を，550 $\mathrm{C}$ で30分間加熱した時の組織であるが，析 川物はケイ素を添加しない場合に比べ非常に細かくな る。しかしこのように密に分布している所の他に析出物 が全然認めら机ない所もあり，その析计は不均一であ る。したがつてこれらの析出物は再結晶終了前にあつた 転位あるい:亜粒界上に生じたものと推定される。

以上のように高温加熱の場合でも析出の初期段階が加 に組織と関係を持つことが明らかとなつた。

ケイ素を添加した場命の析出相もケイ素のない場合と 同様，大部尔が $\mathrm{Al}_{6} \mathrm{Mn}$ 相で $\mathrm{G}^{\prime}$ 相もわずかながら見られ た。また $\mathrm{Al}_{6} \mathrm{Mn}$ 相も長方形の板と不規則的な形をした

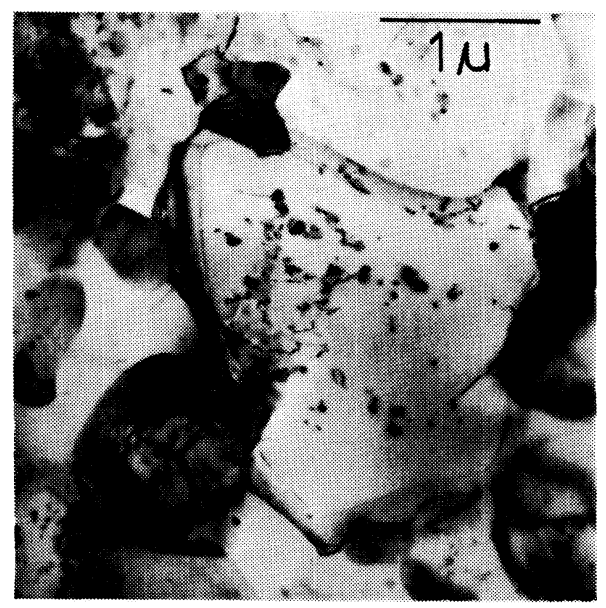

(b)

Photo. $2 \mathrm{Al}_{6} \mathrm{Mn}$ precipitates in subboundaries dislocations, heated at lower temperature.
(A) $350^{\circ} \mathrm{C} \times 125 \mathrm{hrs} . \quad \mathrm{Al}-1.34 \mathrm{wt} \% \mathrm{Mn}$.
(B) $400^{\circ} \mathrm{C} \times 1 \mathrm{hrs}$. Al- $1.29 \mathrm{wt} \% \mathrm{Mn}-0.05 \mathrm{wt} \% \mathrm{Si}$.
(C) $400^{\circ} \mathrm{C} \times 50 \mathrm{hrs}$. Al- $1.29 \mathrm{wt} \% \mathrm{Mn}-0.05 \mathrm{wt} \% \mathrm{Si}$. 
板の 2 種類があつた。

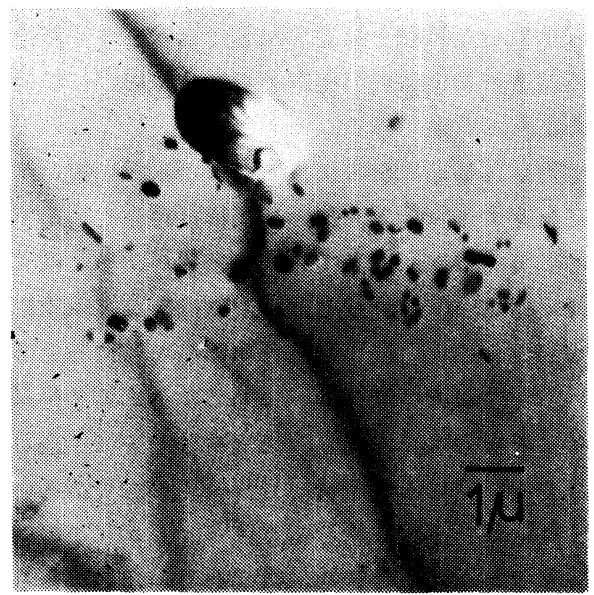

(A) 0 min.

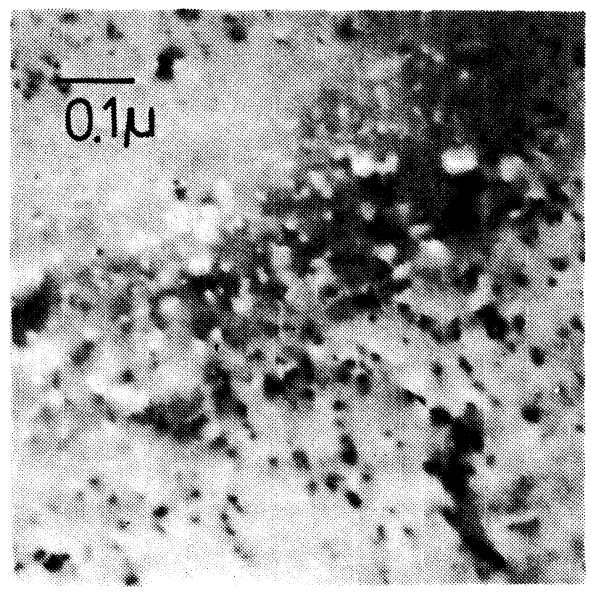

(B) $10 \mathrm{~min}$.

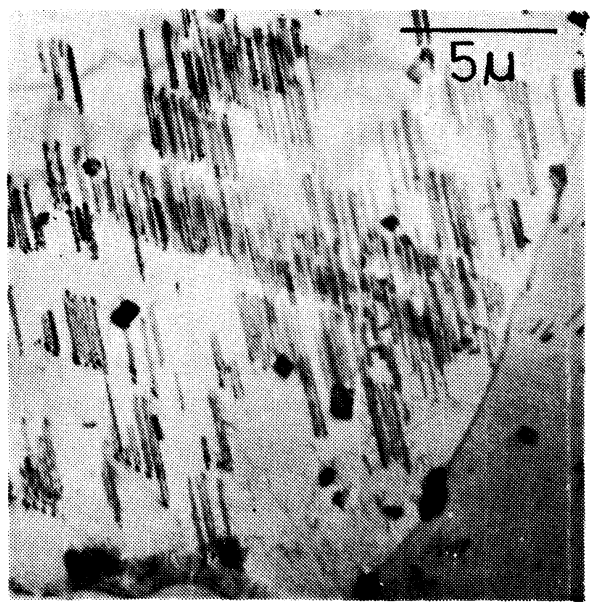

(C) $30 \mathrm{~min}$.

\section{4. 考察}

\section{1 低温と高温での析出機構}

上述のように加に孝行ならと $\mathrm{Al}_{6} \mathrm{Mn}$ 相の析壮が非常 に促進されるが，450`C以上の高温と400年以下の低温で はその様子が異なる。低温での析川促進がきわめて大で ある。

$400^{\circ} \mathrm{C}$ 以下の低温領域では再結晶の進行が遅く, 過飽 和固溶体の分解话数多くの転位からなるセル組織などの 格子久陷部に起こるので, 析州の核生成は容多となる。 ‥方 $450^{\circ} \mathrm{C}$ 上り $400^{\circ} \mathrm{C} の$ 方の析州が速く進むということに より，その成镍に必要なマンガン原子は再結晶が遅延し て残つた転位網を通してのパイプ昖散によつても運ば れ、析州相の成琵も容易である。その結果析州速度は大 となる。

しかもマンガン原子が加ﾞ組織に析什すると，析训の

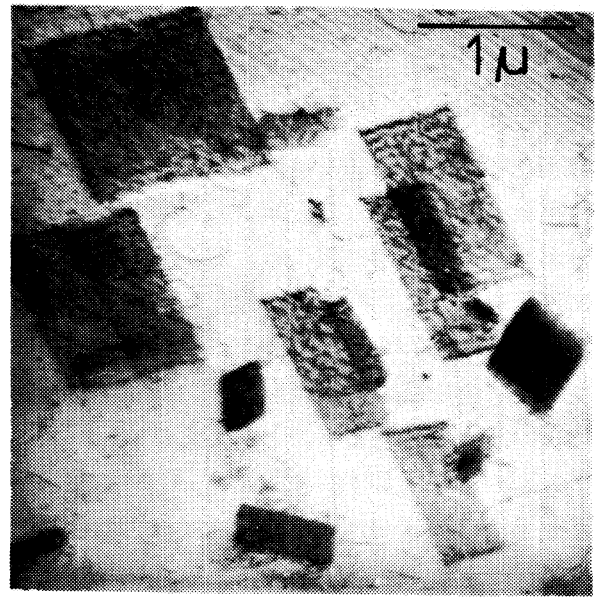

(D) $30 \mathrm{~min}$.

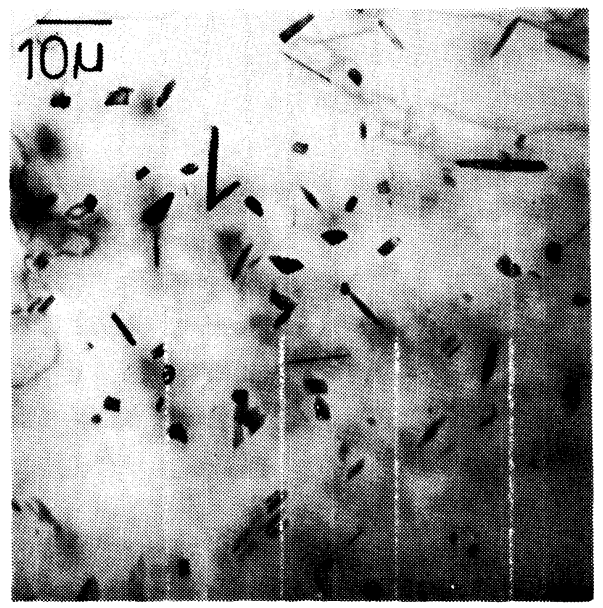

(E) $1200 \mathrm{~min}$.

Photo. $3 \mathrm{Al}_{6} \mathrm{Mn}$ precipitates in $\mathrm{Al}-1.34 \mathrm{wt}^{\circ}{ }_{0}, \mathrm{Mn}$, heated at a high temperature $(5.50 \mathrm{C})$. 

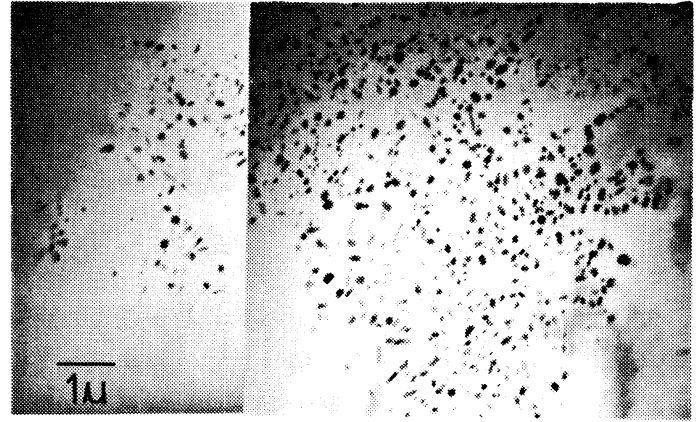

Photo. $4 \mathrm{Al}_{6} \mathrm{Mn}$ precipitates in $\mathrm{Al}-1.29 \mathrm{wt}^{\circ}{ }^{\circ} \mathrm{Mn}-$ $0.05 \mathrm{wt}^{\circ}{ }_{0} \mathrm{Si}$, heated at 5.50 (: for $30 \mathrm{~min}$.

核生成と成卓を助ける。加门組織は多”定化し，その消滅が 困難となる。その結果再結晶が遅机ると同時に析州も非 常に促進さ机ることになる。

このように低温で生じた $\mathrm{Al}_{6} \mathrm{Mn}$ 相の核生成および成 長は格子愐部に起こるので, 析忺にともなう歪エネル ギの緩和は容易であり，析壮相は界面エネルギのみを減 少させるため，丸味を带びた塊状の形態をとるものと考 えられる。

一方 $450^{\circ} \mathrm{C}$ 以上の高温では再結唱の進行が速く, 電気 抵抗は再結昆終了後に大きく減少して抢り，析出過程の 大部分が再結晶終了後に起こる。しかし電子顕微鏡観察 結果に示したように，析活物の分有が不均一であること また高温加熱に㧊いても加にした方の析壮速度が速いこ となどより，析川核の生成は短時閂に終了寸る再結毘の 䦌に加に組織上に起こるものと考えられる。

しかしこのようにして核生成した $\mathrm{Al}_{6} \mathrm{Mn}$ 相は，加： 組織が直ちに消失寸るため, その成素は再結晶したマト リックスゆで起こる。したがつて生成した数多くの析妆 核の内，成垃に有利な条件を满たすものが成厓し，析沙 物がある優先方位にそろつて並ぶことになる。

\section{2 ケイ素添加の影響}

ケイ素を0.05\%だけ添加すると、冷閒加「をした場命 もしない場命にも析州が促進された。加、した場合には $400{ }^{\circ} \mathrm{C}$ 以下の低温加熱で著しい効果が現われ，再結晶の 進行が遅れしかも析计が非常に促進される。

清水ら ${ }^{20)}$ 㳉 $\mathrm{Al}-1.1^{\circ}{ }_{0} \mathrm{Mn}$ 合食に0.6\%のケイ素を添加 すると析出が速めら机ること，析壮物が微細になること などを報告して扔り、これはケイ素が析壮核として働く ためであろうと結論している。彼らの場命，ケイ素の添 加量が多くアルミニウム，マンガン柱よびケイ素を含む 元元化命物が生ずるため, 本研究の場合と様子が異な る。しかし本研究の場合も，0.05\%のケイ素が析汪をき おめて顕著に促進するが，こ机は析川相の界而エネルギ を下げるなどの作用在㧍よぼすことにより析州の核生成 が容㔠になるためと考えら扟る。したがつて核生成位置
が增加し，Photo. 4 で示したように析性物が微細にな つている。

一方加に:した試料を低温加熱した場合，ケイ素の添加 が再結昆遅延就よび析出促進をもたらす原因について，

つぎのように考察できる。

析性が再結晶に㧍よぼす影響には，析出物が冷間加 1.前に存在する場合と，冷間加1:後再結晶を起こす前に 生じている場合上区別して考える必要がある。前者の場 命には，微紐で密に分散した析出物は再結晶阻止作用が あるが，粗大の場合にはむしろ再結晶を速めると考えら れている。本研究の低温加熱で生じた析出物の再結晶阻 此作用は後者の場合であり，析出物は寸でに存在してい る粒界やセル壁に不均一析出し，七ルの成長あるい泣 界の移動を妨げ再結晶を遅延させる。しかしこの場合も 析叫物が加了:組織上に微細に析出した場合とあらく析け した場命では，微細に析出した場命の再結晶阻止効果は 人きいものと考えられる。

ケイ素が添加されると上述のように，高温加熱の際に 生じた析计物治微細になる。(Photo. 4) 高温加熱の場合 も 4.1 で述べたように低温加熱の場合と问様に析出の核 生:成虹加1組織で起こるので，低温加熱で生じた析悄物 もケイ素つ添加こよつて加亡組織に微細に分布するもの と考えられる。その結果ケイ素を添加した場命には，粒 界の移動や七ル壁の移動がより効果的にくぎ止めされ再 結晶阻止作用が大になると考えられる。

析归物と再結晶阻止作用の関係を直接知るためには， 再結晶が終了しない途中の段階で観察しなければならな いが，この段階では電子顕微鏡組織上，加了組織と析川 物の区別をつけることが困難であり，再結晶阻止に有効 な析胜のサイズ，分散状態などについて知ることはで きなかつた。

再結昆が遅れる上，それによつて逆に析蚂がはやめら れるつは，4.1で述べたとおりである。

\section{3 長方形の板状 $\mathbf{A l}_{6} \mathrm{Mn}$ 相について}

Fig. 9 は $\mathrm{Al}-1.3^{\circ} \% \mathrm{Mn}$ 合金を $550^{\circ} \mathrm{C}$ で加熱した時にえ られた長方形の板状 $\mathrm{Al}_{6} \mathrm{Mn}$ 析蜊相とその電子線回折像 を示す。このような形状の $\mathrm{Al}_{6} \mathrm{Mn}$ 相を確認したのは本 研究が始めてであり，加にした場会にのみ生ずるようで ある。

Fig. 9 の下に電子回折像の模式図を示めす。a-a, $\mathrm{b}^{\prime}-\mathrm{b}^{\prime}$ $c-c^{\prime}$ および d- $-d^{\prime}$ が写真のそれらの列と一致する。罒に 挄てて印洨アルミニウムマトリックスによる回折点で あり，印および○印は $\mathrm{Al}_{6} \mathrm{Mn}$ 相による回折点であ る。○印のスポットは写真では見られないが，試料を傾 斜すると見えてくるもので奏際には存在する回折点で女 る。

これらの回折点は四示したよらに指数ずけでき，膜面 

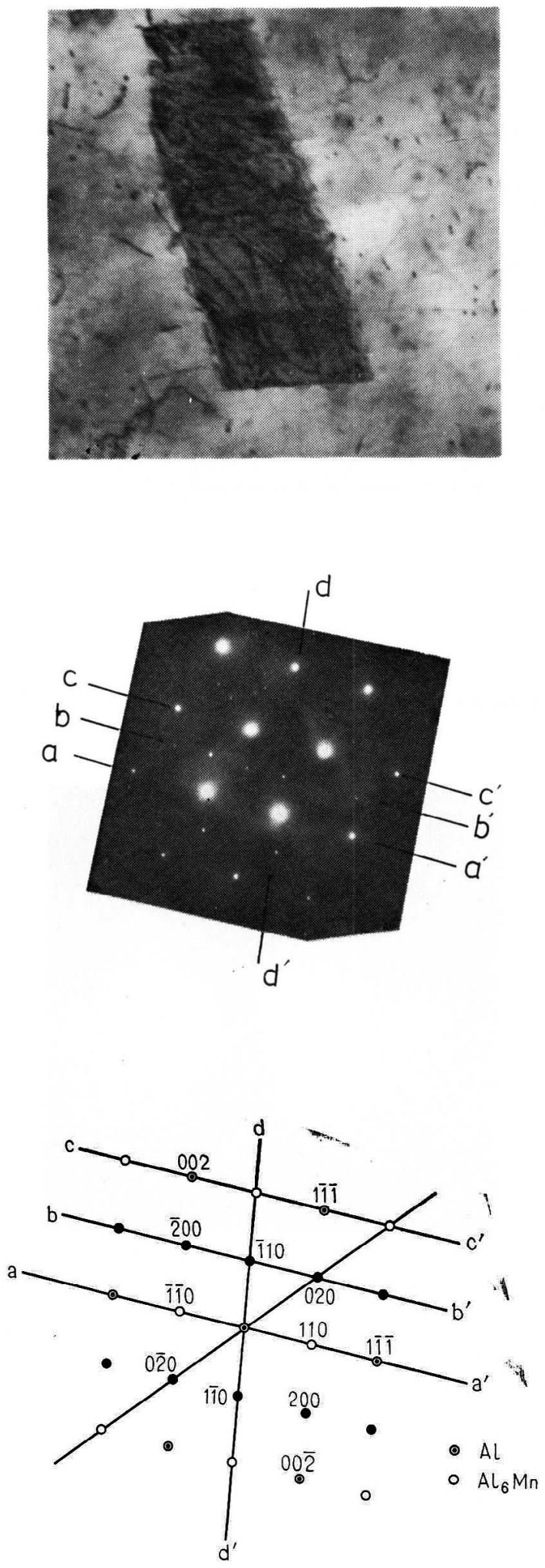

Fig. 9 Diffraction pattern of $\mathrm{Al}_{6} \mathrm{Mn}$ precipitates and Al matrix.
の方向がアルミニウムの[110]方向, $\mathrm{Al}_{6} \mathrm{Mn}$ 相の[001] 方向となり〈110〉 $\mathrm{A}] / /\langle 001\rangle \mathrm{Al}_{6} \mathrm{Mn}$ といら関係がえられ る。

一方ソルミニウムの (110)面と $\mathrm{Al}_{6} \mathrm{Mn}$ 相の(001)面に は，Fig. 10 (a) に示めしたような関係がある。ABCD をアルミニウムの (110)面, $\mathrm{A}^{\prime} \mathrm{B}^{\prime} \mathrm{C}^{\prime} \mathrm{D}^{\prime}$ を $\mathrm{Al}_{6} \mathrm{Mn}$ 相の (001) 面とすると, その対角線の長さ $\overline{\mathrm{AC}}$ は, アルミニ ウムでは $9.92 \AA, \mathrm{Al}_{6} \mathrm{Mn}$ 相では $9.96 \AA$ となり良い一致 を示す。したがつてアルミニウムの (110) 面と $\mathrm{Al}_{6} \mathrm{Mn}$ 相 の(001)面ではその原子の位置が無理なく一致する。

つぎに〈110 $\rangle_{\mathrm{Al}} / /\langle 001\rangle \mathrm{Al}_{6} \mathrm{Mn}$ といら関係がえられて いるので，Fig.10(a)に㧍けるこの 2 つの方向すなわち 紙面に垂直な力向の原子位置の関係を考察したのがFig. 10 (b) である。すると Fig. 10 (a) における $\overline{\mathrm{AC}}$ を一辺 として紙面に垂直な方向を他辺とした矩形 ACEF がえ られ，この矩形の面はアルミニウムの（111）面および $\mathrm{Al}_{6} \mathrm{Mn}$ 相の (110) 面に一致する。この図においての印は アルミニウムの (111) 面に扮ける原子位置, O印は $\mathrm{Al}_{6} \mathrm{Mn}$ 相の (110)面に打けるアルミニウム原子の位置を 示す。ここにおいて $\overline{\mathrm{AC}}(=\overline{\mathrm{EF}})$ の長さは前述のごとく アルミニウムと $\mathrm{Al}_{6} \mathrm{Mn}$ 相の間で良い一致を示す。また $\mathrm{AF}(=\overline{\mathrm{CE}})$ の長さもアルミニウムでは $3 \mathrm{~d}_{\mathrm{Al}}^{(110)}=8.59$ $\AA, \mathrm{Al}_{6} \mathrm{Mn}$ 相では $\mathrm{C}_{\mathrm{Al}_{6} \mathrm{Mn}}=8.87 \AA$ となり良い一致を示 す。したがつて, $\{111\} \mathrm{Al} / /\{110\} \mathrm{Al}_{6} \mathrm{Mn}$ という関係の存 在が期待できる。

な拉， $a_{\mathrm{Al}}$ はアルミニウムの格子定数, $a_{\mathrm{Al}_{8} \mathrm{Mn},} b_{\mathrm{Al}_{6} \mathrm{Mn}}$ および $\mathrm{c}_{\mathrm{Al}_{6} \mathrm{Mn}}$ はそれぞれ $\mathrm{Al}_{6} \mathrm{Mn}$ 相の $\mathrm{a}$ 軸， b 軸および $\mathrm{c}$ 軸の格子定数を示し， $\mathrm{d}_{\mathrm{Al}}^{(\mathrm{h}, \mathrm{k}, 1)}$ はアルミニウムの $(\mathrm{h}$, $\mathrm{k}, \mathrm{l})$ 面の面間距離を示す。

このように加工した場合に生じた板状 $\mathrm{Al}_{6} \mathrm{Mn}$ 相はマ トリックスであるアルミニウムの $\{111\}$ 面上にその板面 を一致させ，しかもその面をそれ自身の $\{110\}$ 面として 析出する可能性がある。しかも $\mathrm{d}_{\mathrm{Al}}^{(111)}=2.37 \AA \simeq 2.49 \AA$ $=\frac{1}{2} \times \mathrm{d}_{\mathrm{Al}_{6} \mathrm{Mn}}^{(110)}$ という関係があるので板状析出物の厚さ 方向にも原子間の良い一致が存在する。

以上のような結晶学的考察からえられる結論は $\mathrm{Al}_{6} \mathrm{Mn}$ 析出相がアルミニウムの $\{111\}$ 面を晶癖面とする可能性 が強いということである。

Fig. 11 は長方形の板状 $\mathrm{Al}_{6} \mathrm{Mn}$ 相とマトリックスの電 子線回折像を示す。この板状析出物はをの板面を試料の 膜面とほぼ平行にしている。一カマトリックスの回折点 の関係より膜面がアルミニウムの $\{111\}$ 面に近いことが わかる。よつてこの板状析出物はアルミニウムの $\{111\}$ 面上にのつて捛り,この面を晶癖面としているものと考 えられる。

この長方形の板状析出相がアルミニムの $\{111\}$ 面上に 析出すれば，前述のように原子間距離に良い一致がある 

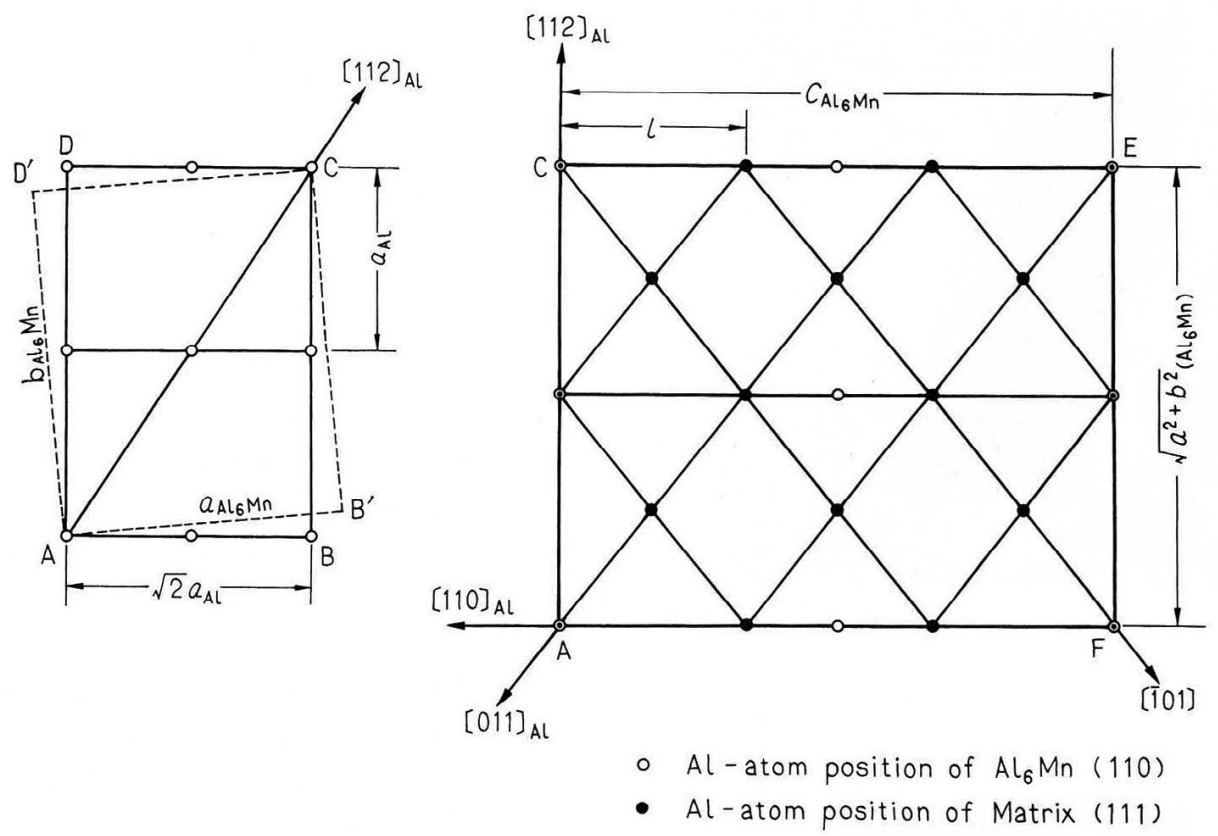

(a)

(b)

Fig. 10 Crystallographic relation between $\mathrm{Al}_{6} \mathrm{Mn}$ precipitates and $\mathrm{Al}$ matrix.
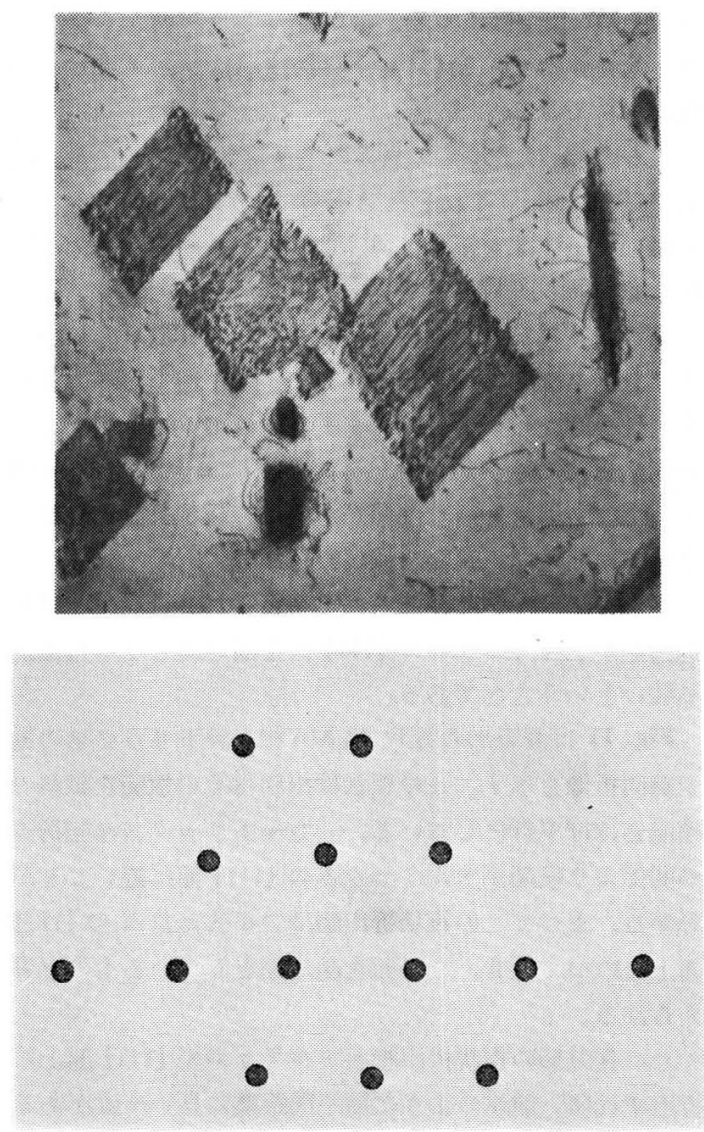

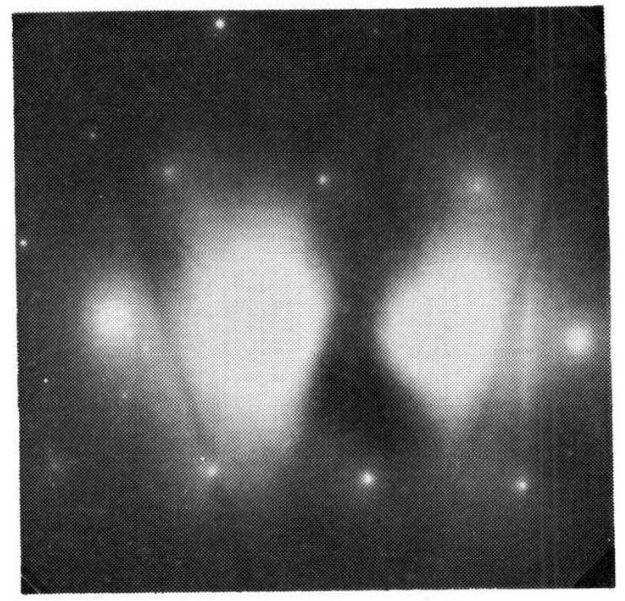

Fig. 11 Determination of crystal habit plane of $\mathrm{Al}_{6} \mathrm{Mn}$ precipitates. 
ため，析出相の小さい間はマトリックスと整合関係を保 つことが可能となる。析出相の初期段階の Photo. $3(\mathbf{A})$ で見られたコントラストはマトリックスとの間に生じた 整合歪みによるものと考えられる。そして析出物が成長 してその整合歪みが増大すると，マトリックスと析出相 の界面に転位を導入して緩和するようになる。Photo. 3

(B) において板状析出物の中に見られる線状のコントラ ストはこれらの界面転位によるものであろう。

しかし Al-Mn 系における析出相は非常に複雑で, $\mathrm{Al}_{6} \mathrm{Mn}$ 相の他に $\mathrm{G}$ 相および $\mathrm{G}^{\prime}$ 相が存在し, その生成条 件も明確でなく，また $\mathrm{Al}_{6} \mathrm{Mn}$ 相も加工しない場合には 違つた形状の，違つた方位関係をもつことが報告されて おり,さらに詳細な研究を要する。

\section{5. 結 論}

$\mathrm{Al}-1.3 \% \mathrm{Mn}$ 扎よび $\mathrm{Al}-1.3 \% \mathrm{Mn}-0.05 \% \mathrm{Si}$ 合金につい て, 高温で溶体化処理後, 冷間圧延を行ない種々の温度 で加熱しその時に起こる再結晶過程を，かたさ，電気抵 抗の測定および電子顕微鏡直接観察によつて調べつぎの 結論をえた。

(1) 析出熱処理前に冷間加工を行なうと析出が非常に 促進される。この促進の機構は $450^{\circ} \mathrm{C}$ 以上と $400^{\circ} \mathrm{C}$ 以下で 異なる。この境となる温度は熱処理温度までの加熱速度 によつて異なる。析出促進は $400^{\circ} \mathrm{C}$ 以下の低温で顕著で ある。

(2) 低温 $\left(400^{\circ} \mathrm{C}\right.$ 以下) では再結晶の終了する前に析出 の大部分が進行するため, 転位やセル組織といつた加工 組織に析出の核生成および成長が起こる。これらの久陷 部での核生成は容易であり，またパイプ拡散によつてそ の成長速度も大きくなる。このようにして生じた析出物 によつて加工組織が安定化しその消失が困難となり, 再 結晶が遅れその結果さらに析出が進む。

(3) 高温 $\left(450^{\circ} \mathrm{C}\right.$ 以上) においては, 冷間加工による析 出促進は低温ほどではない。また再結晶が短時間で終了 しその後で析出の大部分が進行する。高温での析出促進 は再結晶が終了寸る間に, 加工組織で析出の核生成が起 こるためと考えられる。しかしその成長は再結晶したマ トリックス中で起こる。

(4) ケイ素が添加されると, 加工しない場合も加工し た場合もその析出速度は速くなる。しかし加工して 400 `C以下で加熱した時の効果が著しく, 再結晶が遅れる と同時に析出の促進が大きい。これはケイ素が添加され ると析出物が微細となり, その結果再結晶が遅れ, その ため析出が促進されることに原因するものと考えられ る。

(5) 析出相の大部分は低温でも高温でも $\mathrm{Al}_{6} \mathrm{Mn}$ 相で 女り，ケイ素が添加された場合もそうであつた。その形

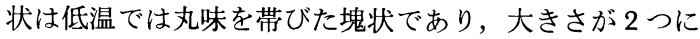
わかれた。高温では今まで加工しない場合に報告されて いる不規則な形をした板の他に，規則正しい長方形の板 も確認された。

(6) 長方形の板状析出相はアルミニウムの $\{111\}$ 面を 晶癖面として $\langle 110\rangle_{\mathrm{Al}} / /\langle 001\rangle_{\mathrm{Al}_{6} \mathrm{Mn}}\{111\}_{\mathrm{Al}} / /\{110\}_{\mathrm{Al}_{6} \mathrm{Mn}}$ といら関係を保持するようである。アルミニウムの (111)面と $\mathrm{Al}_{6} \mathrm{Mn}$ 相の (110) 面の原子間距離の間に良い 一致があり, $\mathrm{Al}_{6} \mathrm{Mn}$ 析出相の小さい間はマトリックス と整合関係を保持できるようである。

謝 辞

本研究において, 電子顕微鏡観察結果の解析にあたり 有益なる討論と適切な助言を戴いた，東北大学の D. エ ールシュレーゲル博士および結果の検討に有益なる助言 を下さつた幸田成康博士に深く感謝の意を表する。

\section{参 考 文 献}

1）清水，中谷：軽金属, No. 4 (1952), 100.

2) 清水, 中谷, 武上: 軽金属, No. 8 (1953), 29.

3）清水, 中谷：軽金属, No. 9 (1953), 14.

4) 清水, 中谷 : 軽金属, No. 14 (1955), 24.

5) 溝口, 西川, 山本 : 軽金属, No. 8 (1953), 25.

6)川島, 中村, 武藤：軽金属, No. 5 (1952), 82.

7) 川島, 中村, 西坂: 軽金属, No. 6 (1952), 23.

8) 川島, 中村：軽金属, No. 7 (1953), 20.

9) 大日方, 畑, 山路：日本金属学会誌, 17 (1953), 496.

10) 市川, 大橋：軽金属, 16 (1966), 120.

11）市川, 大橋：軽金属, 16 (1966), 127.

12）市川，大橋：軽金属, 16 (1966), 304.

13) I. Obinata, D. Oelschlägel and Y. Takeuchi:

J. Inst. Metals., 95 (1967), 158.

14）市川，大橋：軽金属，18 (1968), 97.

15）市川, 大橋：軽金属, 18 (1968), 277.

16) 村上, 森：軽金属, 18 (1968), 339.

17) O. Izumi, D. Oelschlägel and A. Nagata: Trans JIM, 9 (1968), 227.

18) A. Nagata, D. Oelschlägel, Y. Takeuchi and I. Obinata: Trans JIM, 10 (1969), 52.

19) 楠本, 太田：日本金属学会誌, 18 (1954), 446.

20）清水, 中谷, 吉崎: 軽金属, No. 23 (1957), 23.

21) A. Ferrari, P. Friorini and F. Gatto: Aluminio, 35 (1966), 223.

22） D. エールシュレーゲル, 河野, 和泉：軽金属 学会第38回春期大会講演概要, (1970), 37.

23) 長浜, 三木 : 軽金属, 20 (1970), 137.

24) A. F. Polesya and B. M. Pasalsky: Fizika Metallov: Metallovedenie, 26 (1968), 115. 